\title{
Love and homophobia in Malawi's spoken-word poetry movement
}

\author{
Harri Englund
}

By the early 2010s, a number of Malawian poets in their twenties had begun to pursue aesthetic alternatives to the poetry associated with academic writers at the University of Malawi. Although in many cases recipients of tertiary education themselves, the new poets have sought to substitute the elliptical expression of the earlier generation with a language that teems with popular idioms and slang words. As poetry directed at 'the people', its medium is spoken word rather than print, performed to live audiences and distributed through CDs, radio programmes and the internet. Crafted predominantly in Chichewa, the poems also address topics of popular interest, from current affairs to football to trouble with money and love. As such, key figures in the movement did not fail to produce verse about homosexuality after Malawi's controversial 'first gay wedding' in 2009.

The event was an engagement ceremony (unkhoswe) rather than a full-blown wedding (ukwati). Yet it attracted immediate attention both nationally and internationally, and the couple were promptly arrested and charged under Malawi's anti-sodomy laws (Biruk 2014; Demone 2016). Despite the threats by several foreign governments to suspend development aid to Malawi, the couple were sentenced by the courts and then pardoned by president Bingu Wa Mutharika after a visit by the United Nations' secretary general. Malawi was rife with rumours, some of which described the 'marriage' as a conspiracy by which non-governmental organizations had tested the state's willingness to apply legislation inherited from the colonial era. Popular scepticism was fuelled by one of the partners marrying a woman after his release from prison, while the other settled in Cape Town as a transgender person.

The controversy served to galvanize the politicization of homosexuality in Malawi (Currier 2018). Anti-homosexual sentiments found a fertile ground in which to grow in the elitism that had marked Malawian attempts at human rights activism after the restitution of multiparty democracy in the early 1990s (Englund 2006). The emphasis on civil and political liberties, propelled by activists' decision to translate the concept of human rights into Chichewa as 'birthfreedom' (ufulu wachibadwidwe), resonated poorly with the experiences of hunger and economic difficulties among the populace. As elsewhere in contemporary Africa, political and religious opprobrium against homosexuality arose from specific historical conditions, much as it may have depicted the orientation as alien to 'African culture' (Aterianus-Owanga 2012; Boyd 2013; M'Baye 2013).

\footnotetext{
Harri Englund is Professor of Social Anthropology at the University of Cambridge. His most recent book is Gogo Breeze: Zambia's radio elder and the voices of free speech (University of Chicago Press, 2018). Email: hme25@cam.ac.uk

(C) The Author(s), 2021. Published by Cambridge University Press. This is an Open Access article, distributed under the terms of the Creative Commons Attribution-NonCommercial-NoDerivatives licence (http://creativecommons.org/licenses/by-nc-nd/4.0/), which permits non-commercial re-use, distribution, and reproduction in any medium, provided the original work is unaltered and is properly cited. The written permission of Cambridge University Press must be obtained for commercial re-use or in order to create a derivative work.
} 
The spoken-word poets presented here pandered to no politician or pastor. Nor do their verses amount to a silencing of all debate, as appears to have been the intent of certain other popular artists. The successful musician and member of parliament Lucius Banda, for example, stopped his live performance abruptly in 2015 after he spotted two male members of the audience in a romantic embrace. ${ }^{1}$ Beyond their homophobic tone, the poems presented here evoke a plurality of viewpoints, a sense of the poet debating the particular stance he or she has taken in the debate. Such plurality does not make them any less disturbing, but the poets' choice of issues to be raised in debates on homosexuality - and their uses of language - merits close attention. They appear even more complex when seen in the context of their creators' other works. Not only have these same poets performed poetry in the service of progressive campaigns against gender-based violence and the discrimination suffered by people with albinism, they have also penned and performed love poems whose depictions of male and female desires have asserted unusual equality in a popular culture often marred by misogyny.

\section{Born-free poets}

Robert Chiwamba and Evelyn Pangani were among the first to start performing poetry in a deliberate effort to dispense with some of the aesthetic features of modern Malawian poetry. Both were born around 1990 and were thus young children when political and constitutional changes took place. Their trajectories are not identical. Chiwamba, a graduate in public administration at Chancellor College of the University of Malawi, owes more than he may admit to the legacies of literary ferment in that institution. It is Chiwamba who has done the most to represent the new poets as a movement, and his entrepreneurial approach has helped convene the poets for live performances and, since 2016, on the internet platform sapitwapoetry.com, which by 2019 had featured work by over 130 Malawian poets. Pangani, whose highest academic achievement is a diploma in journalism, has been a popular voice in the movement and one of the few female writers and performers. Between 2011 and 2015, she did her part to lend coherence to the new movement by hosting a poetry-reading show on Joy Radio, a commercial station broadcasting from Blantyre. Towards the end of the 2010s, she ceased to release and to perform new poems despite continuing to write them. She cited her becoming a mother and her lack of funds to record the poems as reasons for her withdrawal.

Chiwamba was born in Balaka in southern Malawi to Lomwe and Yao parents. Despite some efforts at ethno-linguistic revivalism since the democratic transition (Kamwendo 2002; Kayira et al. 2019), colonial and postcolonial policies had consolidated Chichewa as Malawi's most widely spoken language by the 1990s, and it was the only language spoken at Chiwamba's home. He found his calling as a poet when he was a student at Chancellor College, initially as a way of entertaining his fellow students with colloquial verse on mundane topics, but he soon developed an ambitious agenda for the new movement. Although he audited lectures and workshops led by academic poets, Chiwamba perceived a gap between what they took to be poetry and the kind of language that would make poetry resonate with

\footnotetext{
'‘Lucius stands by anti-gay position', The Nation, 29 December 2015.
} 
Malawi's populace. The more some of his lecturers questioned the status of his and his peers' writing as poetry, the more determined he became to assert the need for new poetry for new times. Apart from the diminishing need to deploy elliptical expression for political reasons, as discussed below, Chiwamba felt that by the twenty-first century Malawians were generally living in a world of instant communication where proverbial wisdom was becoming obsolete. In one of our conversations, he claimed that proverbs (miyambi) and esoteric idioms (mikuluwiko) had largely disappeared from everyday language. He described the question he posed to himself as follows: 'If people don't understand proverbs, what will I benefit from using them? [Ngati miyambi samva, ndipindula chiyani?]'

Pangani had begun to write poetry as a teenager in her home district of Blantyre and did not share Chiwamba's formative experience as an aspiring poet in a university. She wrote verse in English as a secondary-school student but switched to Chichewa in 2008 to reach a wider audience on the radio. Pangani soon found herself in the company of like-minded writers who, assembled both virtually and in live sessions by Chiwamba and his peers, experienced unprecedented fellowship. Pangani's passion was to write verse about women and girls, particularly about the importance of schooling and the need to reduce the domestic chores that hampered many girls' education. Such messages proved popular among governmental and non-governmental agencies, which invited Pangani to perform at various functions. It is a vocation she has pursued as a teacher of poetry among schoolchildren, sponsored by Save the Children.

The opportunities to perform offered by various organizations are another facet of the movement's public presence. Chiwamba has been a prolific contributor to such events, his portfolio of collaborators including Malawi's ombudsman, UNESCO and the World Bank, along with a number of NGOs. In some cases, the organizations have commissioned poems on particular topics, while in others the poets have performed work from their existing repertoire. Never slow to seize opportunities, Chiwamba has also had the movement adopt annual themes in recent years: gender-based violence in 2017 and discrimination against people with albinism in 2018. Despite their potential to generate income, these campaigns and functions have not made anyone a full-time poet. Pangani sells home-made furniture in Lilongwe, while Chiwamba works for the Malawi Revenue Authority as a tax collector in the remote northern district of Karonga. He prefers the permissive attitude of his superiors there to the more restrictive regime that might prevent his travels if he worked in Malawi's urban centres.

\section{A new aesthetic}

Chiwamba and his peers pursue their vision of a poetry movement in the aftermath of the Malawi Writers Group, which nurtured literary talent during the one-party era led by the 'President for Life' Kamuzu Banda (Mphande 1996; Vail and White 1991: 280-98). Some of its members came to enjoy international publishing success - notably Frank Chipasula, Jack Mapanje, Lupenga Mphande and Paul Zeleza - but the origins of the group lay in youthful enthusiasm not unlike what drives the current movement. Its early interventions in the 1970s also included comparable efforts to bring, through open-air recitals and plays, literary works to wider audiences than could be achieved through its academic base 
at Chancellor College and the other constituent colleges of the University of Malawi (Mphande 1996: 94-6). Such was the stranglehold of Banda's regime on creativity, however, that poetry became the group's principal medium for, as the members saw it, its propensity to disguise politically sensitive observations in indirect and elliptical expression. By the same token, the texts were written rather than spoken, save for the meetings between a select group of insiders, and English became the principal language in which the poetry was written.

The conditions under which the attendant aesthetic arose were severe enough, as attested by Mapanje's imprisonment in 1987-91 and by the exile of older writers, such as Legson Kayira and David Rubadiri. No sooner had Malawi celebrated its independence in 1964 than Banda's autocratic impulses came into view. The 1965 Public Security Regulation gave him the powers to detain without trial anyone accused of holding dissenting views, while legislation in 1968 established the Censorship Board to criminalize possessing, importing, publishing, distributing or displaying any text or other printed matter deemed 'undesirable' by the regime (Mphande 1996: 81). As Mapanje (2002: 184) has recalled, the poets developed a language in which to elude the omnipresent censor by, among other strategies, coining new words such as 'to accidentalise'. A shared 'code of imagery' (Vail and White 1991: 281-2) was key to the poets' work.

The challenge the twenty-first-century spoken-word poets have issued concerns both the aesthetics and the purpose of poetry in the so-called new Malawi. Immediately after Malawi's first multiparty elections in over thirty years in 1994, Mapanje welcomed the new era from exile in the United Kingdom by announcing the need to 'reconstruct the stories of thirty years of Banda's autocratic rule without fear' (1995: 14). He insisted on 'de-autocratization' as the necessary condition for such reconstruction, not only in the structures of government but also in the imaginative resources that writers would draw on. Malawians seized on the new freedoms, however, in ways that the country's internationally best-known poet and the founding member of the Writers Group found hard to condone. A few years after calling for fearless writing, Mapanje bemoaned that the mushrooming newspapers had become 'ebullient to the point of being irresponsible' (2002: 178). Poems, written in English and Chichewa, were a striking feature of the more than a dozen newspapers that began appearing as soon as the political situation allowed (Kishindo 2003). Few of the poets had published before, let alone were members of the Writers Group, but this period 'actually saw the greatest number of published poets in the literary history of Malawi' (Chimombo and Chimombo 1996: 78). Yet while Mapanje regretted the abuse of freedom of expression, the newspaper poets' academic critics noted the 'very uneven quality' that ranged from 'plain statement to true poetry' (ibid.: 86). It is the academic critics' propensity to place themselves as the arbiters of poetic taste that the new spoken-word movement has sought to challenge.

Many of the poets of the early 1990s disappeared with the short-lived newspapers, but Chiwamba, Pangani and their peers would have been too young to participate then. Nor, as mentioned, do newspapers or other print publications play a significant role in the dissemination of their poetry. It was private radio stations rather than newspapers that proved resilient in the media landscape of the new Malawi (Englund 2011: 31-6). Most stations aired regular programmes of poetry recitals, and these contributed to the growth of the spoken-word movement. The spoken-word poets' thematic range in the 2010 s was also considerably 
broader than the preoccupation with politicians and electoral politics in the poems of the early 1990s. Yet the apparently limited aesthetic and technical command of poetry has continued to draw derision from academic critics.

One of those critics is Benedicto Malunga, the long-time registrar at the University of Malawi and a renowned Chichewa poet. Although he published his first poem as a student at Chancellor College in 1981, his preference for writing in Chichewa made him a somewhat marginal figure in the Writers Group. Over the years, his poetry has featured many times on the radio, in the Chichewa curriculum in secondary schools and even on the internet platform curated by Chiwamba, making him the best-known poet in Malawi - ahead of, as he proudly told me, Mapanje, whose fame is largely international, beyond the country's small academic community. He does not, however, see Chiwamba and his peers as carrying forward his legacy in Chichewa poetry. In my conversations with him, Malunga described the new spoken-word poetry as deploying a 'bastardized language' and 'campus humour'. Every generation of students, he asserted, had its campus jokes, but they could hardly become the stuff of poetry. He also dismissed Chiwamba's claim that proverbs no longer featured in Malawians' language by pointing out their frequent use by political and religious leaders. Malunga saw himself as maintaining high aesthetic standards in Chichewa poetry, citing as examples imagery and diction in one of his anthologies (Malunga 2001) and the translations he had prepared. They include the epigraph of W. B. Yeats' poem in his translation of Chinua Achebe's Things Fall Apart (Achebe 2004). In 2018, he was also hoping to finalize his translation of Shakespeare's Julius Caesar before the 2019 presidential and parliamentary elections.

The teachers of literature at Chancellor College have not been more receptive to the new movement. A lecturer in Chichewa told me that he had assigned Chiwamba's poems in the classroom to provoke a debate on what constituted 'real poetry'. Chiwamba's poems served as examples of how not to write poetry, although the lecturer admitted that interesting discussions could ensue when students were confronted with such examples. For this lecturer, Chiwamba's poems were often too long and repetitive, evidence of the poet's inability to use idioms and proverbs to shorten his text. The lecturer saw this lack of technical mastery as a consequence of Chiwamba's study of social sciences rather than literature. The very popularity of his poetry, the lecturer felt, threatened the development of creative writing in Malawian languages. Inspired by Chiwamba, many others could adopt his low standards.

Chiwamba's response to these criticisms was twofold. On the one hand, he was keen to convince me of the care with which he had considered the aesthetic and technical aspects of his poetry. He had attended some of Malunga's lectures on poetry and cited him saying that not all the elements that constituted poetry needed to be present in any given poem. Chiwamba also regretted that all types of poetry were talked about in Chichewa using just one word, ndakatulo. What would, he asked rhetorically, 'spoken word' be in Chichewa? On the other hand, Chiwamba was also anxious to assert a difference between the new movement and the poetry favoured by academics. He was explicit about the entrepreneurial spirit in his efforts to galvanize a spoken-word movement as an expression of views and concerns held by the majority of Malawians. It not only entailed accepting topics that may have been too mundane for more high- 
minded poets; it also required the kind of language people spoke in their own lives, although, crucially, this was enlivened by the poet's humorous and inventive uses of words, some of which were non-standard Chichewa. Repetition was another deliberate aesthetic feature for poems prepared to be performed, not a sign of the poet's incompetence. That critics would continue to dismiss his poems as 'cracking jokes' (kuseketsa) and 'only telling stories' (kungokamba nkhani) was of little consequence to Chiwamba. The popularity of his poetry was his reward.

\section{Debating mathanyula}

Unbeknown to each other, Chiwamba and Pangani prepared poems against homosexuality in the wake of the 2009 controversy over the 'gay wedding' mentioned earlier. Chiwamba's poem Takana mathanyula (We Refuse Homosexuality) was actually his second on the topic, prepared hard on the heels of Mudzafa imfa yowawa (You Will Die a Painful Death), which had described in graphic detail the gruesome demise that awaited homosexuals. The idea for this poem had occurred to Chiwamba before the events in 2009, but its original subjects were armed robbers rather than homosexuals. It may be a measure of the poet's opportunism that he changed the subject as events unfolded, but both Chiwamba and Pangani insisted to me that they stood fully behind the homophobic mood of their poems. Despite his ambition to bring his performances to various national and international stages, Chiwamba even claimed that he would not be deterred by organizers' threats to boycott him. The popular demand for these poems drove their defiance. They enjoyed plenty of airtime on various radio stations, and Takana mathanyula has been one of the most downloaded poems on the movement's website for years. Chiwamba's live audiences have come to expect it as the boisterous finale of his performances, not unlike a pop star belting out his or her greatest hit.

Whether Chiwamba and Pangani met the popular demand simply by parroting what people wanted to hear is a more complex issue than it may seem. On the one hand, they have not used their poetic licence to reform the language in which homosexuality is talked about in Chichewa. The connotations of mathanyula are hardly neutral, let alone conducive to a sympathetic attitude. It summons images of sodomy, and it conveys a sense of coerced sexual acts. Before the current controversies, mathanyula was used for what senior men did to their younger male companions in the same-sex settings of prisons and mines. It was also the word for male rape in other contexts. Activists have struggled to translate 'gay sex' into Chichewa and have often preferred to use English words. On the other hand, Chiwamba and Pangani diverge from the popular norm by de-emphasizing the alleged Christian case against homosexuality. In her poem Ndalama za nyansi sitikuzifuna (We Don't Want Dirty Money), Pangani mentions the issue early on in order to move on to other observations. Both of them did mention to me their Christian faith as one reason for their anti-gay attitudes, but as an Anglican (Chiwamba) and a Roman Catholic (Pangani), they have had no direct association with evangelical and Pentecostal preachers most commonly found to voice public condemnation of homosexuals. In Malawi, as Chiwamba pointed out, the influence has gone the other way, with some pastors citing his poems in their preaching. 
Nor would 'hate speech', or indeed 'homophobia', exhaust the contents of these poems. To be sure, Pangani's poem evokes disease and filth in ways that can only be regarded as demeaning, while Chiwamba's ends with what appears to be incitement to violence. Yet the bulk of both poems addresses Malawi's colonial legacies and its more recent democratic experiments. Chiwamba summons an overwhelming consensus on the anti-gay sentiment by repeating the question about what everyone is saying in the various contexts of everyday lives. $\mathrm{He}$ achieves this mood also by deploying Chiyao and Chitumbuka, Malawi's other major languages, to ask the same question, and by listing several different names for God, as though the sentiment cut across religious divides. At the same time, his poem mimics the new democratic era by conveying the debate on the views one can hold on the issue. They include the claims that anti-gay Malawians are hypocrites for not admitting vices among the heterosexual majority, that Malawi has no distinct culture of its own within which to regard homosexuality as alien, and that consensual sex between adults is no one else's concern. It is Malawian activists and their foreign sponsors who appear in both poems to kill all debate. The crux of both poems is a warning against taking Malawians for granted, however 'polite' or 'mild-mannered' (ofatsa) or 'poor' (osauka) they may seem.

The vitriol aimed at Malawian activists is consistent with popular suspicions about NGOs as strategies for self-enrichment in the new Malawi (Biruk 2018; Englund 2006). In her conversations with me, moreover, Pangani explained her urge to write Ndalama za nyansi sitikuzifuna as a response to what she saw as President Joyce Banda's weakness in resisting foreign demands for gay rights. Although Banda never implemented new policies or laws in this area during her short reign, the female poet felt compelled to protest because of the female president's perceived feebleness. The poems also draw on historical notions to express critical thoughts. Pangani mentions 'colonialist' (mtsamunda), while Chiwamba goes further back in history to summon slavery (ukapolo). In a particularly striking verse, Chiwamba swears that if homosexuality represents freedom, Malawians will choose to return to slavery 'in Egypt'.

Some of the claims and imagery in Pangani's poem derive from her internet searches, such as the evocation of 'twelve diseases' and the emphasis on 'anal cancer'. They indicate the origin of her objections to homosexuality in anxieties that cross national boundaries, whatever the violation of national self-determination that her poem highlights. Indeed, the connotations of sodomy in mathanyula may resonate with popular reflections on sex and power more widely in contemporary Africa (see Geschiere and Orock 2020; Meiu 2020). On the other hand, some of the imagery in both poems, despite Chiwamba's claims about disappearing proverbs and idioms, deploys well-established Chichewa tropes. Among others, they include, in Chiwamba's poem, maliro a njoka (lit. a snake's funeral) for disrespect, kwa mtu wa galu tatemetsa nkhwangwa pamwala toto (lit. hitting a rock with an axe by the dog's head) for ardent refusal, and, in Pangani's poem, kampeni kumphasa (lit. a small knife hidden in a mat) for plotting. Alongside such established idioms are more recent ones, some of which require knowledge possessed by Malawians living in urban areas, such as chintuwitsa mbali inayi for a 'four-sided scone' in Chiwamba's poem. The challenges that these phrases present to the translator are a measure of the ambitious language that the spoken-word poets pursue despite their opposition to academic poetry. 


\section{Gender equality}

The themes of neo-imperialism and neo-colonialism, pitting homosexuality against patriotism, had become common in African anti-gay discourses by the early 2010s. While the two poems described above may have added little to these themes, their popularity helped raise the profile of spoken-word poetry in Malawi and vindicated, for the poets themselves, the aesthetic orientation they had chosen for the movement. As mentioned, however, these poems must not be considered in isolation from their writers' other works. Chiwamba and Pangani have also penned and performed love poems, whose evocation of gender relations unsettles the association often made in the activist literature on homosexuality that anti-gay sentiments uphold a 'heteropatriarchal' social order (Epprecht 2012: 228). Homophobia, in this view, tends to correlate with conservative attitudes to gender relations in heterosexual relationships. Yet when considered with regard to Malawi's male-dominated, often misogynistic popular music, Chiwamba's and Pangani's love poems can appear positively countercultural. Men and women have remarkably similar feelings in Chiwamba's Takumana pano pamsika (We Met Here at the Market), while female desire gets woven into a poem about love and devotion in Pangani's Ngati mawa sindifika (If I Don't Arrive Tomorrow).

Takumana pano pamsika describes a chance meeting between old flames in a market place. Both of them have arrived with their spouses and children, only to become acutely aware of how past desires are not easily extinguished in the present. The symmetry between male and female cravings not only introduces rhythmic repetition to the poem but also asserts an equivalence between the genders. For each gesture, thought and feeling that the poem attributes to one party, it finds the same for the other. The poem's narrator assumes responsibility for failing to marry his old flame in the refrain 'dilly-dallying, my dilly-dallying / Stupidity, my stupidity' (Koma chidodotu ine chidodo / Kupusa ineyo kupusa). The refrain is consistent with the man's role as the active one in courtship, marked in Chichewa by the active tense 'to marry' (kukwatira) for a man and the passive tense 'to be married' (kukwatiwa) for a woman. Yet the poem's egalitarian ethos is such that even this convention gives way to some debate about who bears responsibility for the unfulfilled union. In the end, the couple resolve, as 'religious people' (opemphera; lit. 'those who pray'), to accept the burden of convention in a tearful farewell.

Intimacy between two lovers outweighs any other consideration in Pangani's Ngati mawa sindifika. More lyrical in its praise for romantic love than Takumana pano pamsika, it centres on the prospect of the narrator's sudden death - 'If I don't arrive tomorrow' - and deploys several bodily and natural metaphors to convey the depth of her love. Her heart leaps with joy because of her lover; when closing her eyes, she sees only her lover's image; if the lover is disappointed in politics, she is too. Towards the end, this comparatively short poem gives counsel to the lover in the event of death before it returns to the present bliss in remarkably sensual imagery.

The expression of female desire, written by a female and delivered in a female voice, breaks convention where Takumana pano pamsika appears to suppress emotions for the sake of convention. Yet both poems convey countercultural courage. Ngati mawa sindifika asserts the woman as the active partner in an intimate, sexual 
relationship. Takumana pano pamsika reveals that even 'those who pray' - and a deacon at that - can harbour extramarital passions, not because of wanton lust but as subjects infatuated with memories of past intimacy. The significance of these poems when discussing their 'homophobic' counterparts is not simply the seriousness with which they explore the meaning of romantic love where it often seems absent (Thomas and Cole 2009). If the 'homophobic' poems acquire, in addition to what critics might consider their intrinsic hate speech, a hypocritical quality when compared with the poems written for international organizations, these love poems may help cast some doubt over the charge of opportunism.

Both Pangani and Chiwamba explained to me the autobiographical nature of these poems. Pangani penned hers to be performed at her own wedding. While its origins in celebrating the matrimonial bond may mitigate misogynistic misgivings about female sexuality, the poem nevertheless delivers an alternative to the common trope in Malawian middle-class weddings - the bride as her groom's helper. The hapless narrator in Chiwamba's poem, on the other hand, is to some extent the poet himself. The personal circumstances contribute nuance that the ultimately impersonal attacks on homosexuality lack. The aesthetic of people's poetry shows itself capable of questioning convention.

\section{Acknowledgements}

While I bear the sole responsibility for the accuracy of the transcriptions and translations of their poems, I am greatly indebted to Robert Chiwamba and Evelyn Pangani for their kind cooperation throughout this project, including their patient and insightful discussions with me of these poems line by line, word by word. Ahmmardouh Mjaya at the Centre of Language Studies in Zomba offered further assistance in translating the poems, as did Alick Bwanali and Pascal Kishindo with their reflections on wider issues in Chichewa historical and socio-linguistics.

\section{Supplementary materials}

The following supplementary materials are available with this article at $<$ https://doi.org/10. 1017/S0001972021000255>:

Photographs of the poets: Evelyn Pangani and Robert Chiwamba

The audio recording of Evelyn Pangani's performance of Ndalama za nyansi sitikuzifuna The audio recording of Evelyn Pangani's performance of Ngati mawa sindifika The audio recording of Robert Chiwamba's performance of Takana mathanyula The audio recording of Robert Chiwamba's performance of Takumana pano pamsika

\section{References}

Achebe, C. (2004) Chipasupasu. Translated by B. Wokomaatani Malunga. Zomba: Chancellor College Publications.

Aterianus-Owanga, A. (2012) “L'émergence n'aime pas les femmes!": Hétérosexisme, rumeurs et imaginaires du pouvoir dans le rap gabonais', Politique Africaine 126 (2): 49-68. 
Biruk, C. (2014) "“Aid for gays": the moral and the material in "African homophobia" in post-2009 Malawi', Journal of Modern African Studies 52 (3): 447-73.

Biruk, C. (2018) Cooking Data: culture and politics in an African research world. Durham NC: Duke University Press.

Boyd, L. (2013) 'The problem with freedom: homosexuality and human rights in Uganda', Anthropological Quarterly 86 (3): 697-724.

Chimombo, S. and M. Chimombo (1996) The Culture of Democracy: language, literature, the arts and politics in Malawi, 1992-94. Zomba: WASI Publications.

Currier, A. (2018) Politicizing Sex in Contemporary Africa: homophobia in Malawi. Cambridge: Cambridge University Press.

Demone, B. (2016) 'LGBT rights in Malawi: one step back, two steps forward? The case of R v Steven Monjeza Soko and Tiwonge Chimbalanga Kachepa', Journal of African Law 60 (3): 365-87.

Englund, H. (2006) Prisoners of Freedom: human rights and the African poor. Berkeley CA: University of California Press.

Englund, H. (2011) Human Rights and African Airwaves: mediating equality on the Chichewa radio. Bloomington IN: Indiana University Press.

Epprecht, M. (2012) 'Sexual minorities, human rights and public health strategies in Africa', African Affairs 443: 223-43.

Geschiere, P. and R. Orock (2020) 'Anusocratie? Freemasonry, sexual transgression and illicit enrichment in postcolonial Africa', Africa 90 (5): 831-51.

Kamwendo, G. (2002) 'Ethnic revival and language associations in the new Malawi: the case of Chitumbuka' in H. Englund (ed.), A Democracy of Chameleons: politics and culture in the new Malawi. Uppsala: Nordiska Afrikainstitutet.

Kayira, G. W., P. C. Banda and A. L. Robinson (2019) 'Ethnic associations and politics in contemporary Malawi', Journal of Eastern African Studies 13 (4): 718-38.

Kishindo, P. J. (2003) 'Recurrent themes in Chichewa verse in Malawian newspapers', Nordic Journal of African Studies 12 (3): 327-53.

Malunga, B. W. (2001) Ndidzakutengera kunyanja Ligineti ndi ndakatulo zina. Zomba: Chancellor College Publications.

Mapanje, J. (1995) 'Orality and the memory of justice', Leeds African Studies Bulletin 60: 9-21.

Mapanje, J. (2002) 'The orality of dictatorship: in defence of my country' in H. Englund (ed.), A Democracy of Chameleons: politics and culture in the new Malawi. Uppsala: Nordiska Afrikainstitutet.

M'Baye, B. (2013) 'The origins of Senegalese homophobia: discourses on homosexuals and transgender people in colonial and postcolonial Senegal', African Studies Review 56 (2): 109-28.

Meiu, G. P. (2020) 'Underlayers of citizenship: queer objects, intimate exposures, and the rescue rush in Kenya', Cultural Anthropology 35 (4): 575-601.

Mphande, L. (1996) 'Dr Hastings Kamuzu Banda and the Malawi Writers Group: the (un)making of a cultural tradition', Research in African Literatures 27 (1): 80-101.

Thomas, L. M. and J. Cole (2009) 'Introduction: thinking through love in Africa' in J. Cole and L. M. Thomas (eds), Love in Africa. Chicago IL: University of Chicago Press.

Vail, L. and L. White (1991) Power and the Praise Poem: Southern African voices in history. Charlottesville VA: University Press of Virginia. 


\begin{abstract}
By the early 2010s, a number of Malawian poets in their twenties had begun to substitute the elliptical expression of earlier generations with a language that resonated with popular idioms. As poetry directed at 'the people', its medium is spoken word rather than print, performed to live audiences and distributed through CDs, radio programmes and the internet. Crafted predominantly in Chichewa, the poems also address topics of popular interest. The selection of poetry presented here comes from a female and a male poet, who, unbeknown to each other, prepared poems sharply critical of homosexuality and what they regarded as its foreign and local advocacy. The same poets have also gained success for their love poems, which have depicted intimate desires in remarkably compatible ways for both women and men. The poets who performed 'homophobic' verse went against popular gender stereotypes in their depictions of romantic love and female and male desires. This introductory essay, as a contribution to Africa's Local Intellectuals series, discusses the aesthetic challenges that the new poets have launched in the context of Malawi's modern poetry. With regard to gender relations in their love poems, the introduction also considers the poets' possible countercultural contribution despite their avowed commitment to perform for 'the people'.
\end{abstract}

\title{
Résumé
}

Dès le début des années 2010, plusieurs poètes malawites d'une vingtaine d'années avaient déjà commencé à substituer un langage faisant écho à des idiomes populaires à l'expression elliptique des générations précédentes. En tant que poésie s'adressant " aux gens », son mode est oral plutôt qu'écrit, et elle est déclamée en public et distribuée sur CD, à la radio et sur l'Internet. Ces poèmes, principalement en langue chichewa, traitent aussi de sujets d'intérêt populaire. Les poèmes présentés ici sont ceux d'une poétesse et d'un poète qui, sans le savoir mutuellement, ont préparé des poèmes vivement critiques de l'homosexualité et de ce qu'ils considèrent comme l'action étrangère et locale en sa faveur. Ces mêmes poètes ont également connu du succès avec leurs poèmes d'amour décrivant les désirs intimes de façon remarquablement compatible pour les femmes comme pour les hommes. Les poètes auteurs de vers " homophobes » vont à l'encontre des stéréotypes populaires de genre dans leurs descriptions de l'amour romantique et des désirs féminins et masculins. Cet essai liminaire à la rubrique lettrés locaux de la revue Africa traite des défis esthétiques qu'ont lancés les nouveaux poètes dans le contexte de la poésie moderne au Malawi. S'agissant des relations entre les sexes dans leurs poèmes d'amour, cette introduction examine également la possible contribution contre-culturelle des poètes, en dépit de leur engagement avoué à s'adresser « aux gens ». 


\section{Two poems on homosexuality}

\section{Ndalama za nyansi sitikuzifuna / We Don't Want Dirty Money \\ Evelyn Pangani}

Ndinu olemera inde

Indeed you are rich

Kwanuko mtereshi, tofu, ndalama sizisowa

At your place there is no lack of cash, dosh, money ${ }^{1}$

Galimoto, ndege mumapanga nokha, ndikudziwa

Car, aeroplane you make on your own, I know

Koma mukakhala muzane

But when you are together, you should tell each other

Kukakhala kuyera khungu ndi kwanu

Being light-skinned is your own business ${ }^{2}$

Ife ndalama za nyansi sitikuzifuna

We don't want dirty money ${ }^{3}$

Paja mumati tikamakamba nkhani iyiyi tisamatchulepo Mulungu

You say when we talk about this issue, we must not mention God

Mwati, 'olo, unatilenga koma nkhani iyiyi ndi yapansi pompano'

Saying, 'Although it created us, this issue is about worldly matters'

Chabwino ndavomera, sindikambapo za Baibulo

Alright, I agree, I shall not talk about the Bible

Ngakhalenso nalonso mwamvemve lidanena

Although it also says very clearly

Kuti mathanyula ndi nyansi zenizeni pamaso pa Mulungu

That homosexuality is proper filth in God's eyes ${ }^{4}$

Munakhala bwanji inu, kuipa moyo kumeneku bwanji?

How come you are like that, wishing others ill?

Nthawi zonse kampeni kumphasa ndi ife

Every time plotting against $u^{5}$

Pansi mtedza Malawi

Malawi, be alert ${ }^{6}$

\footnotetext{
${ }^{1}$ Mtereshi and tofu are slang expressions for 'money' (ndalama); they are less common than makobidi, which the poet chooses not to use.

${ }^{2}$ Being 'light-skinned' (kuyera khungu) is considered desirable in Malawi, and its rejection is an early sign of defiance in the poem.

${ }^{3}$ When money is nyansi, it is 'dirty', not only for its illicit or immoral aspects, but also because it is repulsive in a visceral sense.

${ }^{4}$ Nyansi is translated here as 'filth'.

${ }^{5}$ Kampeni kumphasa is a common idiom for plotting and evokes 'a small knife' (kampeni) hidden under 'a mat' (mphasa).

${ }^{6}$ Pansi mtedza is an idiomatic command that urges vigilance against an impending threat. It literally asks to 'hide the groundnuts' and was used in this sense to warn against marauders.
} 
Bwenzi ili ndi lachiphamaso

This friendship is hypocritical ${ }^{7}$

Zolowere nkudyere mwana ndiye uyu

Familiarity with that one results in eating a child ${ }^{8}$

Unkati ndiwe bwenzi pobweranso utathamangitsidwa ngati mtsamunda

You were saying you were coming again as a friend after you had been chased away as a colonialist ${ }^{9}$

Unkati utithandiza pachuma chidziyenda bwino

You were saying you would help us run the economy well

Koma chipalanilaneni ubwenziwu chikuchitika n'chiya?

But since this friendship began, what has been happening?

Udanenanso kuti tisinthe ulamuliro pofunika demokalase anthu azidzilamulira mwaufulu

You also said that we should change governance for people to rule themselves freely in

a democracy

Molemekezanso wachibadwidwe

With respect for birth-freedom ${ }^{10}$

Koma lero akutilamulira ndi nda?

But who is ruling us today?

Pokukukhulupirirani kuti ndinu anzeru

Believing you that you were wise

Poona kulemera kwa maiko anu

Seeing the wealth of your countries

Tidatsata ndondomeko zonse za kayendetsedwe ka chuma

We followed every plan of managing the economy

Ngakhale dongosolo la kamedwe ka mankhwala kuchipatala

Even the plan of administering medicine at hospital

Koma lero chikuchitika pachuma m'dziko muno n'chiya?

But today what is happening to the economy in this country?

Pano poti kwalowa njoka udatisasa

Now that the snake has come you throw us out ${ }^{11}$

Ukuti tikonze kaye njira zathu zoyendetsera chuma

You are saying we should prepare our own ways of managing the economy

Tikazilongosola ubweranso

When we are putting them in order, you come again

Tsono apa ukubweranso ukuti tikapanda kuvomereza amuna adzikwatirana

Now that you are coming again, you are saying that if we don't allow men to marry men

Akazinso okhaokha sutithandiza

Or women to marry women, you will not help us

\footnotetext{
${ }^{7}$ Chiphamaso is something that 'kills the eyes' and obscures the true state of affairs. It is commonly translated as 'hypocrisy' by English-speaking Malawians.

8،Eating a child' (kudyere mwana) likens duplicitous friendship to witchcraft (ufiti).

${ }^{9}$ Mtsamunda is an established idiom for 'colonialist' and evokes the figure as stealing agricultural land.

${ }^{10}$ Wachibadwidwe refers to ufulu wachibadwidwe, 'birth-freedom', and is the most common gloss for 'human rights' in Malawi.

${ }^{11}$ Kwalowa njoka, 'the coming of a snake', expresses an economic downturn and udatisasa, 'you throw us out', deploys the verb kusasa, which is commonly used for 'brushing off dust' to describe how Malawians are treated during a downturn.
} 
Pakuti tikuphwanya ufulu wachibadwidwe

Because we are violating the birth-freedom

Chibadwidwe ukunena iwecho ndiye chiti?

What birth-freedom are you talking about ${ }^{32}$

Ngati ukufuna moyo wathu osangonena bwa?

If you want our life, why don't you just say so?

Zikakhala ndalama ndi zanu

If it is money, it is yours

Ife ndalama za nyansi sitikuzifuna

We don't want dirty money

Malingaliro ako pa ife ndi oipa nthawi zonse

Your thoughts on us are bad every time

Bwanji umatinamiza nthawi zonse?

How come you lie to us every time?

Ndife osauka inde

Indeed we are poor

Koma ife siouma mitu

But we are not dull ${ }^{13}$

Malawi walero osauka ali ndi mawu

Today's Malawi, the poor have something to say ${ }^{14}$

Paja demokalase udati ndi boma la anthu lochita zomwe anthu akufuna

As you said, democracy is the government by the people to do what the people want

Koma lero ukufuna bomali lidzichita zofuna nda?

But today who is it that wants the government to meet demands?

Nanga bwanji polimbikitsa za mathanyulazi

And what about when encouraging that homosexuality

Sukutichenjeza za matenda khumi ndi awiri owopsetsetsawo?

You did not warn us about the dangerous twelve diseases? ${ }^{15}$

Bwanji sukutichenjeza kuti tisanayambe kuchita za nyansizi mwaufulu

How come you did not warn us that before we start making that filth freely

Tiyambe tamanga zipatala za khansa

We should build cancer hospitals

Ndi kuphunzitsa madotolo ochuluka akadaulo wakhansa wa kotulukira chimbudzi?

And train several doctors to specialize in anal cancer? ${ }^{16}$

Kutinso HIV idapezeka koyambirira mwa amuna okhaokha amathanyula 1979

mpaka 1981

Or that HIV was found only among homosexual men from 1979 to 1981

Isanapezeke mwa anthu ena

Before it had been found in other people?

Sukunena zimenezi bwa?

How come you don't say that?

\footnotetext{
${ }^{12}$ Throughout the poem, the 'you' being addressed is the disrespectful second-person singular $i w e$, along with its verbal prefix $u$-.

${ }^{13}$ Ife siouma mitu summons the idiom of being 'dry-headed' (kuuma mutu) in a denial that Malawians are dull or stupid.

${ }^{14}$ Malawi walero, 'today's Malawi', alludes to a previous era when poor Malawians were taken for granted by the political elite as acquiescent subjects.

${ }^{15}$ Matenda khumi ndi awiri, 'twelve diseases', comes from the poet's internet searches and is never detailed in the poem.

${ }^{16}$ The poet expresses 'anal' with recourse to chimbudzi, a word for both toilet and faeces.
} 
Za anamphulika a ululu ogwira ziwalo za manyazi omwe ukuti azichiritsidwa ku nyansizi

About the blistering swellings in private parts that you say will be healed through filth? ${ }^{17}$ Simukunena bwa?

How come you don't say?

Zoti amuna ochita mathanyula adzayenera kumavalanso matewera

That men doing homosexuality also have to wear nappies

Ena ataika muzikhwama paulendo kamba ka chimbudzi chomwe chidzangotuluka ngati kasupe

Some they put into a suitcase when travelling for faeces will flow like a fountain

Bwanji simukunena?

How come you don't say?

Ikadzaphulika miliri khumi ndi iwiriyo pa kamodzi

When those twelve epidemics erupt at once

Mudzathana nayo bwanji inu mwakonzeka kulowa m'gulu la ochita mathanyulalo?

You who are ready to join the group doing homosexuality, how will you finish them?

Ndalama sigula moyo m'dzikumbukira

Money does not buy life, remember that

Lamoyo phukusi umasunga wekha

The bundle of life, you take care of it by yourself 18

Malungo enieniwa akutipha

That big fever is killing us

Nanga ikabwera miliri khumi ndi iwiri yowopsayo

What about when those twelve serious epidemics come

Tidzatha bwanji?

How will we manage?

Atithera mudzi mathanyula

Homosexuals finish off our village

Pobweretsa matenda ovuta kutchula

By bringing diseases whose names are hard to mention ${ }^{19}$

Edzi ikuwatha kale anthu m'midzimu

AIDS already finished off people in the villages

Kulili ikabwera miliri inayi?

What about when the other epidemics come?

Musadayambe kuchita mathanyula awa fufuzani

Before you have started doing that homosexuality, investigate

Matenda ena mutalowetse munowa

You will enter other diseases here

Adzatha dziko lonseli

They will finish off the whole country

Nthawi yokana kukakamizidwa kuchita zinthu tsopano yakwana

Time to refuse being forced to do things has now arrived

\footnotetext{
${ }^{17}$ The genitalia are not named in the poem but are expressed through the euphemism ziwalo $z a$ manyazi, 'embarrassing body parts'.

${ }^{18}$ Lamoyo phukusi, 'of life, the bundle', deploys a common lyrical device in Chichewa poetry to put the attribute before the noun. In ordinary language, the phrase would be phukusi la moyo.

${ }^{19}$ Matenda ovuta kutchula, 'diseases whose names are difficult to mention', is a euphemism for venereal diseases, such as the 'anal cancer' mentioned earlier.
} 
Ngakhale ndi zovuta koma tingathe

Although it is difficult, we shall be able

Kuzichotsa unyolo olamuliridwabe ndi azungu ngakhale tili pa ufulu

To remove the shackles of being ruled by white people even when we have freedom ${ }^{20}$

Ndalama za nyansi sitikuzifuna

We don't want dirty money

\section{Takana mathanyula I We Refuse Homosexuality Robert Chiwamba}

Ndiye inu mukuti bwa? Awo akuti bwa? Iwo akuti bwa?

So, what are you saying? What is that one saying? What are they saying?

Tonse tikuti takana mathanyula

We are all saying that we refuse homosexuality

Inuyo mukuti bwanji? Awowo akuti bwanji? Iwowo akuti bwa?

You there, what are you saying? That one there, what is helshe saying? What are those

ones saying?

Tonse tikuti takana utchisi wokwatirana amuna kapena akazi okhaokha

We are all saying that we refuse the filth of men marrying men or women marrying women ${ }^{21}$

Dzana munabwera monong'ona kudzatinyengerera

The other day you came quietly to lure us

Kuti mwabweranso ndi kaufulu kena

That you had come again with another small freedom ${ }^{22}$

Kokwatirana amuna kapena akazi okhaokha

Of men marrying men or women marrying women

Mwina tingakakonde

Perhaps we might like it

Tinakuuzani

We told you

'Get out'

Get out

Utchisi sitimapanga

Filth we do not make

Dzulo munabwera ndi anzathu odziyesa okha ozindikira

Yesterday you came with our friends who think they alone are clever

Kaya mumati amabungwe omenyera ufulu

You say they are organizations fighting for freedom

Ufulu wa mimba zawo, za achagogo awo ndi za chakazawo

The freedom of their bellies, of their grandparents and of their wives

Kudzatiuza kuti mwabwera nawo am'dziko lathu lomwe

To come and tell us that you came with our own compatriots

Anthu achipala chimodzi omwe akuvomereza zimenezi

People of the same anvil accepting those things ${ }^{23}$

\footnotetext{
${ }^{20}$ Unyolo, 'shackles', associates a contemporary lack of freedom with historical bondage.

${ }^{21}$ Where Evelyn Pangani uses nyansi for 'dirt', Robert Chiwamba's choice, with similar connotations of filth and unhygienic practices, is utchisi.

${ }^{22}$ Kaufulu renders ufulu, 'freedom', in the diminutive.

${ }^{23}$ 'Anvil' is the literal meaning of chipala, referring here to people of the same mould.
} 
Nafe tisaumiritse mtima

We shouldn't be hard-hearted

Tinakuyankhani si ife maliro a njoka

We answered to you that we were not without respect ${ }^{24}$

Musatitengere kokatiyesa koma mutipulumutse kuzakwaipa muvulala

You should not put us in temptation but you should save us from evil, you get injured ${ }^{25}$

Lero ngati sizinamveke mwabwera ndi kamzungu

Today as if it was not clear, you came with a little white person

Katanyamula chintuwitsa mbali inayi

Who had brought a four-sided scone ${ }^{26}$

Kumatiopseza mwati tikapanda kuvomera nyansi zaufuluzi

To scare us that if we do not agree with the filth of that freedom

Anyamula chintuwitsa chake

Helshe will take away his/her scone

Ndipo tikhaula, tigona ndi njala

And so we will suffer, we will sleep with hunger

Ife tikuti basopu

We are saying, 'Watch out'27

'Get out'

Get out

Nyamukani inuyo, okumenyerani ufuluwo ndi chintuwitsa chanu

Leave you lot, the ones fighting for that freedom with your scone

Mudzipita musatitengere kokatiyesa

You must go, you should not put us in temptation

Inuyo mukuti bwanji? Awowo akuti bwanji? Iwowo akuti bwa?

You there what are you saying? That one there, what is helshe saying? What are those ones saying?

Tonse tikuti takana mathanyula

We all say we refuse homosexuality

Tawamveni amalawi akuyankhula kumisika, m'maminibasi ndi kumijigo ndi kumababashopuku akuti bwanji?

Listen to them, Malawians are talking in markets, in minibuses, at boreholes and in

barbershops, what are they saying?

Onse akuti mathanyula amawanyansa ngati makhololo a nkhumba

All are saying that homosexuality disgusts them like the pig's phlegm

Ndithu monga bulu okakamizidwa kutsinje tafika

Indeed like donkeys forced to a river we have arrived

Koma madzi okha sitimwa madolo

But the water we the brave ones will not drink

Mbamba ngati mathanyula ali ufulu

I swear if homosexuality is freedom

Tonse aMalawi tasankha kubwerera kwa Aiguputo kuwukapolo

All of us Malawians choose to return to slavery in Egypt

\footnotetext{
${ }^{24}$ Maliro a njoka, 'the snake's funeral', is the fate of those lacking respect and honour.

${ }^{25}$ Both 'you should not put us in temptation' (musatitengere kokatiyesa) and 'you should save us from evil' (mutipulumutse kuzakwaipa) draw on biblical Chichewa.

${ }^{26}$ The scone stands for a bribe, and chintuwitsa received its name from smearing flour (kutuwa) on its eater's lips.

${ }^{27}$ Basopu, for 'watch out', comes from the Afrikaans passop.
} 
Ndithu zotiuza kuti m'chilengedwe chanu

Indeed to tell us it is natural 28

Kukhala ndi chilakolako kwa mwamuna kapena mkazi mnzanu

To live with a desire among men for fellow men or women for fellow women

Kwa mtu wa galu tatemetsa nkhwangwa pamwala toto

We refuse in the strongest terms ${ }^{29}$

Mbwerera zanu tazimva, utsiru wanu tawuona

Your nonsense we have heard, your foolishness we have seen

Makani anu atikwiyitsa

Your stubbornness has angered us

Taunika chilichonse choyenera kuunikidwa

We examined everything that had to be examined

Tapeza kuti ndi mbwerera, sitingavomere anta

We found it is nonsense, we cannot agree

Kuti ndevu ndi ndevu zipsopsonana, mwikho

That a beard would kiss a beard, a taboo ${ }^{30}$

Sitingalulutire, lipstick ndi lipstick, akupsopsonana, malaulo

We cannot ululate lipstick kissing lipstick, a bad omen ${ }^{31}$

Mukauzane kuzipinda kwanu kokambiranako

Go and tell each other in your meeting rooms

Takana mbwerera

We refuse nonsense

Si inu kodi munabwera pa dzana kudzatiuza

Was it not you who came the other day to tell us

Titsatire demokalase

We should adhere to democracy

Ulamuliro wa chigulu?

The rule of the majority?

Lero chigulu chikuyankhula

Today the majority is speaking

Chikuti takana mathanyula

It is saying we refuse homosexuality

Ana m'mwe n'kuti cici? Werewo akuti cici? Wawodyo akuti cici?

What are you saying? What is that one saying? What are they saying?

Wosope tukanire mathanyula

We are all saying that we refuse homosexuality

Sono imwe mukuti uli? Awo akuti uli? Iwo akuti uli?

You there, what are you saying? That one there, what is he/she saying? What are those ones saying?

Ise tonse tikuti takana mathanyula

We are all saying that we refuse homosexuality ${ }^{32}$

\footnotetext{
${ }^{28}$ Chilengedwe as 'nature' and 'natural' derives from the verb for 'creating', kulenga. It refers to all those things, human and non-human, created prior to and independently of any earthly creature's efforts.

${ }^{29}$ The poet combines two separate idioms for ardent refusal - kukanitsa kwa mtu wa galu (to refuse strongly by the head of a dog) and kutemetsa nkhwangwa pamwala (to strike an axe on the rock).

${ }^{30}$ Mwikho has been adopted into Chichewa from Chilomwe, an endangered language, and its connotations of prohibition are commonly translated as 'taboo' by English-speaking Malawians.

${ }^{31}$ Malaulo is a sign of possible future misfortune and is derived from kulaula, a verb for cursing.

${ }^{32}$ The previous four italicized lines are in Chiyao and Chitumbuka, languages with large numbers of speakers in southern and northern Malawi respectively.
} 
Choyamba mathanyula ndi tchimo lomwe Yehova, Mphambe, Ngwazi, Chiwothamisi Firstly, homosexuality is a sin that Jehovah, God, Hero, the Almighty,

Chilengathambo, Osaodzera, Madalamadala, Kumtunda adana nawo koopsa

The Creator of Clouds, the One Who Never Slumbers, the Elder of Elders, the Top One hates profoundly 33

Ndipo amatha kulanga ndi osachita nawo omwe bola ngati ali m'dzikolo

And it can punish even those who don't practise it as long as they are in this country

Ndiye mumabwera ndi timfundo tanu topoyira

So, you come with your small confused ideas

Ati bwanji inuyonso mumachimwa, kuba, kugona ndi akazi kaya amuna osakhala anu, kutamba mkati?

Saying, 'Don't you sin too: theft, sleeping with a woman or a man not your own, bewitching?'

Koma ndi liti lomwe munamva kuti kutamba kwathu tikufuna kuti kukhale ufulu?

But when did you hear that we want our witchcraft to be freedom?

Ndikuti ndi liti lomwe munamva kuti umbava ndi uhule wathu tikufuna womerezedwe ngati ufulu?

I am saying: when did you hear that our robbery and prostitution should be accepted as freedom?

Ndi liti tikuti munamva tikufuna ufulu woyankhula miseche?

When was it, we are saying, when you heard us wanting the freedom of speaking in swear words?

'Shut up'

Shut up

Tonse takana mathanyula

We all refuse homosexuality

Chachiwiri, mathanyula amatsutsana ndi chikhalidwe cha Chimalawi komanso cha umunthu

Secondly, homosexuality is against the Malawian culture as well as humanity

Ndiye china chimaimika mkono

And so, a thing raises its arm ${ }^{34}$

Ati 'chikhalidwe chake n'chiti?

Says, 'What is that culture?

Azimai athu akumavala maleggingiwa

Our women can wear leggings

Si chikhalidwe chathu, tilibe chikhalidwe cha Chimalawi ife, osatinamiza'

It is not our culture, we don't have a Malawian culture, don't lie to us'

Kodi ngati tilibe chikhalidwe chathu

If we don't have our culture

Unduna wachikhalidwe timakhala nawowa

The Ministry of Culture we have

Ndi wachikhalidwe cha kuti kapena ku Djibuti?

Is about culture from where or from Djibouti?

'Foolish'

Foolish

Tonse takana mathanyula

We all refuse homosexuality

\footnotetext{
${ }^{33}$ The poet's list of God's names does not include the most common one - Mulungu. Like Mulungu itself, many of the names predate Christianity and Islam.

${ }^{34}$ The poet places the subject in the class of inanimate nouns.
} 
Chachitatu, mathanyula ali ndi kuthekera kothetsa mtundu wa anthu a m'dziko lathu Thirdly, homosexuality has the potential to finish the humankind in our country

Poti ana samabadwa m'menemo

For children are not born in it

Ndiye chamathanyula china chimafunsa 'mtundu utha bwanji poti ena adzikwatirabe amuna kapena akazi n'kubereka ana?'

So, another of the homosexuals asks, 'How does the humankind end when others will still marry men or women and give birth to children?'35

Kupusa basi, ndani adzikuberekera ana kuti udzipanga nawo mathanyula?

Simply stupid, who would make children for you to do homosexuality with?

Shupiti

Stupid

Tonse takana mathanyula

We all refuse homosexuality

Ndiye akumadzakhalanso ndi timfundo tina

So, they also have other small ideas

Ati 'zochitika pakati pa anthu akuluakulu oti agwirizana kuchipinda zitayeni sizikukhudzani'

Saying, 'What happens between consenting adults in a room, let it be, it is not your concern' Chiyani?

What?

Bwanji, mchemwali akagona n'mchimwene wake ngakhale ali aakulu timamanga?

How come we arrest a sister and brother who sleep together even if they are adults?

Pachifukwa chomwechinso zikutikhudza ndipo awa timanga

Because it concerns us and we arrest them

Akawamasula, timanganso

When they release them, we arrest them again

Tikangomva amasulidwanso apolisi athu akawamanganso

As soon as we hear that they have been released again by our police, we go and arrest them again

Kungomva mphekesera zoti akutuluka, ife kuwadikirira panja ndi kuwamanganso

To hear only the rumour that they are coming out of prison, we are waiting for them outside to arrest them again

Njinga saimbira belu pakaliyala

The passenger does not ring the cycle bell ${ }^{36}$

Malawi asiyereni amalawi apange okha malamulo

Leave Malawians alone to make their laws

Ndiye kwa inu amabungwe omenyera ufulu wa mimba zanu

And you from the organizations that fight for the freedom of your bellies

Amene mukumatuma anthu kuti adziyesa zida muwapweteketsa ndipo basobu

You who send people to test weapons to hurt people, watch out

Osamatiputa dala, kumatiponda zala, potiona ofatsa

Don't provoke us deliberately, don't step on our toes just because we seem polite 37 
Kufatsa sikupwambana titha kumenya mambama ${ }^{38}$

Being polite is not being stupid, we can slap

Timachitira dala, poyesa pokambirana timvana

We try our best to discuss and understand each other

Koma inu mwati 'zokambirana a-a'

But you say, 'No discussion'

Koma kumatiopseza 'chithandizo tilanda'

But you threaten us, 'We take away aid'

Uku mukukisana pambalanganda

At the same time, you are kissing in the open ${ }^{39}$

Komatu muwasamale anthu akutoperani mafana

Indeed, be careful, people have become tired of you lads

Ulendo wina sadzakupititsaninso kupolisi anta

Some other time they won't take you to the police, no

Adzangokuthyolani mphafwa

They will just pierce the liver

\section{Two poems on romantic love}

\section{Ngati mawa sindifika I If I Don't Arrive Tomorrow Evelyn Pangani}

Lero lino tili limodzipa

Right now that we are together

Mitima yathu isanadukize m'bebe uwu ukumvekawu

Before our hearts are broken ${ }^{40}$

Dziwa ndimakukonda

Know that I love you

Pomwepa tikulankhulana apa

When we are talking to each other over there

Dziwa m'mlingaliro mwanga suchoka

Know that you won't leave my thoughts

Pomwepa tikugwirana zikhathopa

When we are holding each other by the palms of our hands

Mtima wangawu ukuyambasa iwe

My heart searches blindly for you

Mgundo ukugunda m'mtimamu ndi wachimwemwe chifukwa cha iwe

The heart is beating happiness because of you

N'katseka masowa mwadala

When I close the eyes deliberately

Kutsinzina mongothyolera

Eyes closed, the neck turned to one side ${ }^{41}$

\footnotetext{
${ }^{38}$ The italicized words are in Chiyao.

${ }^{39}$ Mukukisana deploys the slang version of 'kissing'. The verb was kupsopsonana earlier in the poem.

${ }^{40}$ The imagery is of hearts stopping for a moment because of future suffering already anticipated.

${ }^{41}$ Mongothyolera alludes to kutyolera khosi, 'to lean the neck', a feminine gesture in courtship and flirting.
} 
Chako chithunzithunzi ndicho ndimachiona

Your image is what I see

Kukadzacha tsiku lina ine osadzuka

One sunrise I will not wake up

Zambiri usadzalire

Do not cry too much

Chimodzi chokha udzagwetsere msozi

Once only shed a tear

Ndicho chikondi chakhatakhata titsanuliranachi

This love we pour for each other is thick ${ }^{42}$

Kuwala kwa dzuwa kokomaku

The sun's beautiful brightness

Kuomba kwa mphepo ya yaziyazi

The cool breeze blowing

Sindikumva kukoma ukandikhumudwitsa

I won't feel the sweetness if you disappoint me

Pena dziko likamaseka pogirigrishidwa ndi zisudzo achita andalewa

Sometimes the country laughs when tickled by politicians' dramas

Sizindikomera ukakhumudwa

They don't please me if you are disappointed

Mwina mawa sindifika

Maybe I don't arrive tomorrow

Chimodzi chokha udzadzitame nacho

Only one thing you should praise yourself for

Unapangitsako moyo wanga kukoma

You made my life sweet

Dziko langa unapangitsa kukhala lokwanira

You made my world sufficient

Ngati mawa sindifika

If I don't arrive tomorrow

Dziwa unali wanga wapamtima

Know that you were my dearest

Lero lomwe lino tiye kugombe la nyanja

Right now let us go to the lakeside

N'kakuchengete monga wakowako namwino

I will go and take care of you as your very own nurse

\footnotetext{
${ }^{42}$ The imagery is of the lovers pouring a thick substance into each other's containers.
} 


\section{Takumana pano pamsika I We Met Here at the Market \\ Robert Chiwamba}

Takumana pano ndi pamsika

We met here at the market

Ndi mkazi amene ndinkamufunitsitsa kwambiri

With a woman I used to desire passionately

Nayenso adandikondetsetsa koopsa

She too used to be madly in love with me

Koma chidodotu ine chidodo

But dilly-dallying, my dilly-dallying 43

Kupusa ineyo kupusa

Stupidity, my stupidity

Ndakumana naye ali ndi amuna ake ndi tiana tawo tiwiri

I meet her she is with her husband and their two small children

Nanenso ndili ndi akazi anga ndi tiana tathu tiwiri

I also have my wife and our two small children

Akunamizira kuwamwetulira amuna ake chonsecho akumwetulira ine

She is pretending to smile at her husband, all the while smiling at me

Nanenso kudzanamizira kumwetulira akazi anga pansi pamtima ndikumwetulira iye

I also pretend to smile at my wife, while with all of my heart smiling at her

Wandiphinyira diso kundilozera amuna ake mwachinsinsi cha mayi

She winks at me to point out her husband to me as a woman's secret

Nanenso ndamuphinyira diso ndikumulozera akazi anga mwachikondi cha bambo

I also wink at her to point out my wife to her as a man's love

Pakanakhala kuti palibetu iwo akanandihaga uyu

Had he not been there, she would have hugged $m e^{44}$

Pakanakhala palibe akazi anga ndikanamuhaga uyu

Had my wife not been there, I would have hugged her

Takumana pano ndi pamsika

We met here at the market

Ndi mkazi amene ndinkamukondetsetsa kwambiri

With a woman I used to love very much

Nayenso adandimvetsetsa koopsa

She also used to understand me extremely well

Koma chidodotu ine chidodo

But dilly-dallying, my dilly-dallying

Kupusa ineyo kupusa

Stupidity, my stupidity

Ndikukumbukira tinkakulira limodzi padzana

I remember we grew up together in the past

Ndithu tinkachezera mugulu limodzi ifeyo

Indeed, we used to hang out in the same group

Ndikadwala ankathamanga kudzandiona ndi kundilimbikitsa

When I fell ill, she used to run to see me and to encourage me 
Nayenso zikamuvuta ndinkakhala lake thandizo lopezekeratu

When she also ran into difficulties, I used to be her reliable helper

Tinkasekererana ndi kusereulana koopsa

We used to make each other happy and to tease each other a lot

Tinkangokhala ngati chibwenzi

We just used to be like lovers

Tonse tinkadziwa kuti ndinkamufuna

We both knew I wanted her

Inenso ndinkadziwa kuti ankandikonda

I also knew she loved me

Takumana pano ndi pamsika

We met here at the market

Ndi mkazi amene ndidamuona okongoletsetsa chilengeleni dzikoli

With a woman I have seen to beautify the world since its creation

Nayenso akundiona owoneka bwino koopsa

She also sees me as extremely good-looking

Koma chidodotu ine chidodo

But dilly-dallying, my dilly-dallying

Kupusa ineyo kupusa

Stupidity, my stupidity

Tikufunatu tonse tipeze mpata tiyankhulane

We both really want a chance to talk to each other

Koma tonsetu mumsika muno talowa ndi achikondi athu

But we both came to the market with our dearest

Sikuti achikondi athuwa sitimawakonda

It is not that we don't love our dearest

Koma mtima inu mtima makani nanunso mukudziwa

But the heart, as you know, is a stubborn heart

Anthu amene tidakondana kuchokera kalekale

People we have loved for a very long time

Anthu amene tidadziwana kuchokera kusikelo

People we have known since the infant scales ${ }^{45}$

Mitima yathu ikufuna itasenderanso chifupi

Our hearts want to come closer

Khutu langa likufuna litamvanso mawu ake

My ear wants to hear again her voice

Mapirikaniro ake nawonso akufuna atamva mawu anga

Her ears also want to hear my voice 46

Koma musaiwale inu ndi mumsika muno tabweramo ndi okondedwa athu ndi ana athu

But you must not forget that we came to this market with our dearest and our children

Takumana pano ndi pamsika

We met here at the market

Ndi mkazi amene ndinkamukondetsetsa kwambiri

With a woman I used to love very much

\footnotetext{
${ }^{45}$ The imagery is of intimacy arising from knowing each other ever since postnatal health checks.

${ }^{46}$ While the previous line uses khutu for 'ear', the word here is mapirikaniro, adopted from Chiyao.
} 
Nayenso adandikondetsetsa koopsa

She also loved me very much

Koma chidodotu ine chidodo

But dilly-dallying, my dilly-dallying

Kupusa ineyo kupusa

Stupidity, my stupidity

Tiana tathutu tatsogola tikudutsana tisakudziwana

Our small children are in front and pass each other by without knowing

Kuti mayi awa ndi ine tikanatha kukhala makolo awo

That this mother and I could have been their parents

Pakamwa pathu pakufunitsitsa patayankhulana

Our mouths yearn to speak

Koma tikuyenera kungodutsana ngati sitikudziwana

But we just have to pass by as if we didn't know each other

Chifukwa panapita nthawi yaikulu tisanaonane

Because a long time has gone since we saw each other

Komaliza n'kamene anandiimbira lamya ukwati wanga ndi mayiwa n'tamanga

The last time was when she called me on the phone after I had married that woman

Akulira kundifunira zabwino

She was crying and wishing me well

Nanenso chaka chimodzi m'mbuyo mwake n'kuti ntalira pomufunira chabwino chimodzimodzi

I also cried a year later while wishing her well in the same way

Takumana pano ndi pamsika

We met here at the market

Ndi mkazi amene ndinkamukondetsetsa kwambiri

With a woman I used to love madly

Nayenso andimvetsetsa koopsa

She also understood me extremely well

Koma chidodotu ine chidodo

But dilly-dallying, my dilly-dallying

Kupusa ineyo kupusa

Stupidity, my stupidity

Wanamatu kwa amuna ake ndi kukhulupirira kuti waiwala china chake

She did trick her husband into believing that she had forgotten something

Si uyu akubwerera wakungofuna kundiona?

Is it not her who is coming back only wanting to see me?

Nanenso ndikunama kwa akazi anga ndionjezere mayunitsi

I also trick my wife that I need to buy more airtime

Mwina ndikumana naye

Maybe I will meet her

Ndakumana naye apayu ndi mkazi amene ndidamukondetsetsa kwambiri

The one I met there is the woman I loved very much

Akundimwetulira ndipo kuoneka bwino kwake ndi konkuja ngati sanachembezeko

She is smiling at me and looking as good as back then as if she had not aged ${ }^{47}$

Inenso ndikuoneka bwino lomwe ngati kale

I also look as good as in the past

Tikukhumba zina zake m'tima mwathu

We yearn for certain things in our hearts

\footnotetext{
${ }^{47}$ 'Ageing' in a woman deploys the verb kuchembeza, which means childbearing.
} 
Ndikumuitana m'mene tinkatchulirana kale kuti mbuzi

I call her a goat like we used to name each other in the past

'Mbuzi iwe n'chifukwa chiyani sunandivomere?'

'You the goat, why didn't you accept me?'48

'Mbuzi iwe n'kanavomera bwanji usanandifunsire?'

'You the goat, how could I have accepted before you had proposed to me?'

Takumana pano ndi pamsika

We met here at the market

Ndi mkazi amene ndidamukondetsetsa kwambiri

With a woman I loved madly

Nayenso adandimvetsetsa koopsa

She also understood me extremely well

Koma chidodotu ine chidodo

But dilly-dallying, my dilly-dallying

Kupusa ineyo kupusa

Stupidity, my stupidity

Takomedwatu tikukumbatirana ngati simumsika

We get carried away in embrace as if it was not at the market

Nthawi ikutichepera koma achikondi akudikirira

Time is short for us as our dearest are waiting for us

Akuliratu mwana wamkazi

She indeed is crying, the female child

Nanenso sindingapirire misonzi ikulengeza

I cannot prevent either tears from forming

Sitingapange chibwenzi chaseritu

We could not have a secret affair ${ }^{49}$

Ndife opemphera

We are religious people

Takumana pano ndi pamsika

We met here at the market

Ndi mkazi amene ndidamukondetsetsa kwambiri

With a woman I loved very much

Koma sadakhalepo wanga

But she was not to be mine

Nayenso adandikonda koopsa

She also loved me very much

Koma sindinakhaleko wake

But I was not to be hers

Chidodotu ine chidodo

But dilly-dallying, my dilly-dallying

Kupusa ineyo kupusa

Stupidity, my stupidity

'Mwinatu kudalembedwa anthu okondana zedi asamakwatirane?' akundifunsa

'Perhaps it is written that people who love each other enormously should not marry?'

she asks me 
Pano zaka khumi m'mabanja athu

Now ten years have passed in our families

Koma timakumbukiranabe tikuuzana

But we tell each other we still remember each other

Vuto lake mafoni namba sitingagawane

The problem is we cannot share phone numbers

Tingadzalowe m'kuyesedwa

We could be put into temptation

Nthawi yatha msanga, make mwana angandifunse mafunso ndikumutsanzika

Our time is finished quickly, my child's mother may ask me questions and I bid her goodbye

Kulakalaka kumupsopsona

Wanting desperately to kiss each other

Koma ndangokumbukira ndine dikoni komanso pano ndi pamsika

But I just remember that I am a deacon and here is at the market

'Tenga handikachifi yanga, nawenso kwaya yangayi uzikandikumbuka ngati sitidzakumananso'

'Take my handkerchief, take it to remember me if we never meet again'

'Nawenso kachite chimodzimodzi' akundiuza

'You too do the same,' she is telling me

Chifukwa chiyani nthawi zambiri Mulungu simumalola anthu omwe tinagwirizana ndi

kukondana koopsa

Why so often God does not allow the people we agree with and love very much

Kuti tikwatirane n'kutipatsa ena m'chikondi chathu?

To marry us but gives us others for our love?

Koma tikuganizirabe ajawa

But we are still thinking about these ones

Ajawa mukuwadziwa inu mukuwadziwa

These ones, you know them, you know them

Tinakumana paja panali pamsika

Where we met was at the market

Ndi mkazi amene ndidamukondetsetsa koopsa

With a woman I loved very much

Nayenso adandikonda movuta

She also loved me passionately

Koma chidodotu ine chidodo

But dilly-dallying, my dilly-dallying

Kupusa ineyo kupusa

Stupidity, my stupidity

Mkazi ameneyu, tsiku lina, tsiku lina

That woman, some other day, some other day

Koma inu, tsiku lina

Ah you, some other day

Ayi zikomo

Ah, thank you 